\title{
REVIEW
}

\section{Metabolic and infectious pathologies in Brazilian medical literature: a review}

\author{
Mauricio Rocha-e-Silva \\ Hospital das Clínicas, Faculdade de Medicina - São Paulo/SP, Brazil.
}

OBJECTIVE: This review of original reports on metabolic and infectious diseases that were recently published in Brazilian journals is designed to inform the readership of CLINICS about their content.

METHODS: I conducted a search in PubMed for original research articles (clinical or basic research) recently published (2008-2009) by Brazilian medical and biological periodicals. Papers on metabolic pathologies were retrieved by searching for appropriate keywords such as metabolic syndrome and obesity. Papers on infectious disease were obtained by entering 15 different keywords for the most commonly occurring pathologies. Review articles, editorials, letters to the editor, and case reports were manually excluded. Selected titles were then categorized into appropriate sub-categories.

RESULTS: This search produced a total of 123 articles, which filtered down to 72 articles after eliminating editorials, review articles, letters to the Editor and case reports. Reviewed periodicals were Arquivos Brasileiros de Cardiologia, Arquivos Brasileiros de Endocrinologia e Metabologia, Brazilian Journal of Biological and Medical Research, Brazilian Journal of Infectious Diseases, Jornal de Pediatria, Jornal de Pneumologia, Revista da Associação Médica Brasileira, Revista da Escola de Enfermagem da Universidade de São Paulo, and São Paulo Medical Journal. The articles were then briefly summarized.

KEYWORDS: Metabolic syndrome; Obesity; Brazilian periodicals.

Rocha-e-Silva M. Metabolic and infectious pathologies in Brazilian medical literature: a review. Clinics. 2010;65(8):809-814.

Received for publication on June 17, 2010; First review completed on June 17, 2010; Accepted for publication on June 17, 2010

E-mail: mauricio.silva@pobox.com

Tel.: $55113069-6235$

\section{INTRODUCTION}

This review of original reports on recently published metabolic and infectious diseases in Brazilian journals is designed to alert the readership of CLINICS about such reports. As of August 2010, an e-book of each new issue will be made freely available through our site at www.clinics. org.br. Over the next 18 months, we expect to compile e-books dating back to the first issue of CLINICS published in February 2005. In this sense we hope to effectively highlight the production of other Brazilian Medical Periodicals.

\section{METHODS}

I conducted a PubMed search for recently published papers (2008-2009) in a nine Brazilian journals which were the most likely sources of original articles on the reviewed subjects. The product of this search was then filtered to eliminate case reports, editorials, letters to the editor, and review articles. Papers on metabolic pathologies were searched for using the keywords "metabolic syndrome" and "obesity" in the abstract. Papers on infectious patho-

Copyright (c) 2010 CLINICS - This is an Open Access article distributed under the terms of the Creative Commons Attribution Non-Commercial License (http:// creativecommons.org/licenses/by-nc/3.0/) which permits unrestricted noncommercial use, distribution, and reproduction in any medium, provided the original work is properly cited. logies were retrieved with the keywords "AIDS," "HIV," "hepatitis," "pneumonia," "meningitis,," "staphylococcus," "streptococcus," and "syphilis." The following journals were found using this procedure: Arquivos Brasileiros de Cardiologia, Arquivos Brasileiros de Endocrinologia e Metabologia, Brazilian Journal of Biological and Medical Research, Journal of Infectious Diseases, Jornal de Pediatria, Jornal de Pneumologia, Revista da Associação Médica Brasileira, Revista da Escola de Enfermagem da Universidade de São Paulo, and São Paulo Medical Journal. A grand total of 123 articles were retrieved, leaving 72 after the filtering procedure.

\section{Original research on metabolic pathologies}

Diabetes and insulin resistance. As might be expected, diabetes and insulin are the major subjects in these papers. Type 1 Diabetes is analyzed in three papers, while Type 2 Diabetes is the subject of nine articles. Santos et al. ${ }^{1}$ evaluated the frequency of metabolic syndrome among adults with type 1 diabetes mellitus according to the criteria of the International Diabetes Federation, the National Cholesterol Education Program, and the World Health Organization and concluded that the latter set of criteria may be preferable in identifying patients in this group, because of better sensitivity. Rollim et al. ${ }^{2}$ prospectively evaluated the efficacy and safety of using insulin glargine to metabolically control type 1 diabetes mellitus in children younger than eight years old and concluded that it was as 
efficacious as Neutral Protamine Hagedorn commonly refered to as NPH but presented a better safety profile, as disclosed by the lower incidence of nocturnal and severe hypoglycemic episodes. Xavier et al. $^{3}$ described the periodontal status of children and adolescents with type 1 diabetes mellitus and concluded that the duration of diabetes and poor glycemic control were significantly associated with periodontal disturbances, suggesting a higher susceptibility of this population in developing probing depth. Panarotto et al. ${ }^{4}$ compared the treatment of type 2 diabetic patients from a private clinic with that of patients who were cared for by a public health service and found that the initial A1c and the frequency of visits have a greater impact on the control of diabetes than the place where the patients are treated. Geloneze et al., ${ }^{5}$ Madeira et al., ${ }^{6}$ and Mendes et al. ${ }^{7}$ discussed insulin resistance and pancreatic beta cell function and the use of the homeostatic model assessments HOMA1-IR and HOMA2-IR as quantifiers thereof. Ferreira et al. ${ }^{8}$ described the epidemiological characteristics of diabetic patients treated in the public health system and suggested that the socio-demographic and clinical characteristics detected in these patients can lead to the proper management and prevention of diabetes in primary health care. Silva et al. ${ }^{9}$ described the impact of abdominal fat and insulin resistance on arterial hypertension in non-obese women and concluded that arterial hypertension is associated with insulin resistance, central fat distribution, and higher leptin levels. Vasques et al. ${ }^{10}$ studied the ability of anthropometric and body composition indicators to predict insulin resistance and found that the anthropometric indicators of central obesity, waist perimeter, and sagittal abdominal diameter show a greater ability to identify insulin resistance in men. Authors indicate that studies in women and elderly people are needed to find the best cut-off points for the entire population. Caldas et al. ${ }^{11}$ described the relationship between insulin and hypogonadism in men with metabolic syndrome and concluded that hypogonadism was associated with insulin resistance and may be a marker of metabolic abnormalities. Ferreira et al. ${ }^{12}$ described the effects of metformin on blood pressure and glucose metabolism in monosodium glutamate-induced obese, spontaneously hypertensive rats. They also emphasized the role of hepatic insulin resistance on metabolic syndrome and pointed out that beneficial cardiovascular effects and improved insulin sensitivity were observed.

Hormones and signaling. Leptin and adiponectin are highlighted in four papers. Da-Paz-Filho et al. ${ }^{13}$ described a decrease in leptin production by adipose tissue in obesity associated with severe metabolic syndrome, suggesting a state of relative leptin deficiency in obesity that is associated with advanced stages of the syndrome. Hinuy et al. ${ }^{14}$ showed that the polymorphism G2548A in the leptin promoter is associated with increased plasma leptin and body mass index scores in Brazilian women and that it has an important role in regulating plasma leptin levels and body mass index in this population. As mentioned above, Silva et al. ${ }^{9}$ showed the impact of abdominal fat and insulin resistance on arterial hypertension in non-obese women and its relation to higher leptin levels. Geloneze et al. ${ }^{15}$ assessed the relationship between adiponectin and metabolic parameters in severely obese women during surgically induced weight loss and concluded that improvements in insulin resistance and adiponectin levels were related to the surgically induced weight loss, suggesting an important role of adiponectin in HDL-cholesterol regulation.

Other papers on signaling include a report by Piccoli et al., ${ }^{16}$ who performed a case-control study analyzing the association between the $894 \mathrm{G}>\mathrm{T}$ endothelial nitric oxide synthase gene polymorphism (NOS3) and MS in 616 subjects and found that $894 \mathrm{G}>\mathrm{T}$ plays a significant role in the mechanistic interaction between metabolic risks such as hypertension and MS, although sex-related differences may exist. Cercato et al. ${ }^{17}$ studied the N363S polymorphism in the glucocorticoid receptor gene and concluded that its prevalence is low in the Brazilian population; though rare, its presence may contribute to the worsening of the individuals' metabolic profiles. Madeira et al. ${ }^{18}$ described the impact of obesity on metabolic syndrome components and adipokines in prepubertal children, providing evidence of the influence of obesity on metabolic syndrome components and on adipokine levels in prepubertal children, which in turn indicates that these components may contribute to the onset of cardiovascular diseases.

The interaction of metabolic syndrome with the female reproductive life cycle is discussed in five papers highlighted here: Buzzinaro et al. ${ }^{19}$ reported on the incidence of high body mass index scores in adolescent offspring among the children of mothers with hyperglycemia during pregnancy, adding that such patients should be followed from childhood. Rivera et al. ${ }^{20}$ evaluated the association between pubertal gynecomastia and body mass index and concluded that a significant correlation occurs between pubertal gynecomastia and a higher body mass index in adult life. Bonganha et al. ${ }^{21}$ evaluated the relationship between resting metabolic rate and the body composition of postmenopausal women and concluded that body composition correlates with lean mass and waist circumference. Tavares at al. ${ }^{22}$ studied the effects of physical activity on gestational weight gain and birth weight of pregnant women in Campina Grande, northeast of Brazil, and found that all the pregnant women were sedentary in the third trimester and that there was a significant association between physical activity patterns and gestational weight gain in the second trimester but that there was no association between this pattern and birth weight. Balen et al. $^{23}$ reported on a murine model of protein restriction in pregnant and non-pregnant rats and concluded that protein restriction in pregnancy modified maternal metabolism, altering lipid synthesis in the liver and hormonal profiles and decreasing the placental and fetal masses.

Epidemiological and other studies. Silva et al. ${ }^{24}$ compared the prevalence of a high body mass index (BMI) and central adiposity in a sample of 287 adult subjects in a rural community of the state of Minas Gerais, Brazil. High BMI was found in $24.8 \%$ of the population $(37.4 \%$ of females; $11.5 \%$ of males). Central adiposity was associated with higher total cholesterol, LDL, triglycerides, fasting glucose, lower HDL, arterial hypertension, dyslipidemia, and hyperglycemia. A similar study by Vedana et al. ${ }^{25}$ arrived at comparable conclusions for the extreme south of Brazil. These results confirmed the potential effect of body composition shifting, especially at the abdominal level and on lipids, glucose metabolism, and blood pressure levels in rural populations. Coltro et al. ${ }^{26}$ evaluated cardiovascular risk factors in a population attending a community event on health education and found a significant association between obesity, dyslipidemia, and arterial hypertension, 
emphasizing the need for educational programs to promote primary prevention, mainly for the elderly and overweight. Metabolic syndrome was also identified as a risk factor for arterial hypertension by Nascente et al. ${ }^{27}$ in a small Brazilian city. Fernandes et al. ${ }^{28}$ examined risk factors for obese adolescents. Excessive weight was associated with the male gender, studying in a private school, and mothers with higher education levels, revealing a need to implement initiatives to fight obesity in the school environment and reach the whole family structure while taking genderrelated specificities into consideration. On the whole, these studies show that obesity is spreading from big cities into smaller towns and the rural areas of the country. In contrast, Coutinho et al. ${ }^{29}$ found that risk factors associated with low birth weight included extremes of reproductive age, poor education, low maternal weight, smoking beyond the fourth month of pregnancy, previous cesarean section, an interdelivery interval $<24$ months or $>37$ months, a maternal history of hypertension, cardiopathy, premature delivery, few $(<5)$ prenatal visits, initiation of prenatal care late in the pregnancy (after the $3^{\text {rd }}$ month), premature rupture of membranes, increased blood pressure, infectious diseases, and hemorrhages during the current pregnancy; however, maternal obesity was a protective factor. Finally, two studies found that the progressive intermingling of Brazilians of Japanese origin with other cultures led to an increased incidence of metabolic syndrome in the resulting offspring. ${ }^{30,31}$ Haun et al. ${ }^{32}$ compared the waist-height ratio in a population of 968 inhabitants of the city of Salvador, Brazil with a number of other indicators and found that indicators of abdominal obesity are better for discriminating coronary risk than body mass index. Two separate studies noted the effects of physical activity or inactivity on metabolic syndrome. ${ }^{33,34}$ Santos et al. ${ }^{35}$ described associations between weight loss, bone mass, body composition, and dietary intake of post-pubertal obese adolescents. Prado et al. ${ }^{36}$ described the effects of long-term multidisciplinary inpatient therapy (reduced energy intake, dietetic education, physical exercises and psychological therapy) on the body composition of 728 extremely obese adolescents, showing that such a procedure allows a significant reduction in severe obesity; normal growth was preserved and the percentage of fat-free mass. Fernandes et al. ${ }^{37}$ evaluated the effect of nutritional education on the prevalence of high BMI/obesity and foods eaten at primary schools and found that despite its short duration, there were improvements in the quality of the food the schoolchildren who attended the course were eating. Abulnaja $^{38}$ described an association between obesity and acne in Arabian adolescents.

Diehl et al. ${ }^{39}$ described an interesting association between lipodystrophy and AIDS/HIV. Serpa Neto et al. ${ }^{40}$ compared waist-height ratio to other indicators of obesity as predictors of high coronary risk. Volterra et al. ${ }^{41}$ described the effects of neuroendocrine obesity induction on systemic hemodynamics and left ventricular function in normotensive rats. Orpheu et al. ${ }^{42}$ detected a time dependent increase in the demand for body contour surgery in massive weight loss patients from pretreatment through bariatric surgery and subsequently over a three-year follow up. Kurebayashi et al. ${ }^{43}$ analyzed nurses' perceptions about diseases that are treated by acupuncture and found that it was used to treat obesity among other morbid situations.
Diagnosis. Rech et al. ${ }^{44}$ carried out a validation study for the use of bioelectric impedance to measure fat-free body mass. Rodrigues et al. ${ }^{45}$ analyzed resting metabolic rate by indirect calorimetry in obese patients and found that a tendency towards underestimation of self-reported caloric intake exists among obese women and that the failure to lose weight in some patients can be due to their low level of physical activity. Chaves et al. ${ }^{46}$ used abdominal ultrasound and magnetic resonance imaging to evaluate non-alcoholic fatty liver disease diagnoses in morbidly obese patients and found significant agreement between the ultrasound method and the hepatic biopsy, which indicates a need to implement and perform more research on the use of ultrasound and to validate these methods. Reliance of such procedures could minimize the need to perform biopsies to detect and diagnose such diseases.

\section{Original research on infectious diseases}

As might be expected, the pandemic of HIV / AIDS is the most frequently studied pathology in this chapter. Articles fall into various categories, with some articles falling into more than one category.

Epidemiology. Bassichetto et al. ${ }^{47}$ estimated the incidence of HIV-1 in the city of São Paulo from November 2000 to April 2001, comparing epidemiological and sociobehavioral data of recently infected individuals with those individuals with long-standing infection. A less sensitive than standard ELISA was employed to identify recent infection. The overall incidence of HIV-1 infection was $0.53 \%$ /year, whereas overall HIV-1 prevalence was $3.2 \%$ higher among males vs females. Recent infections accounted for $15 \%$ of the total infected population and correlated with being younger and male. Szwarcwald et al. ${ }^{48}$ described a methodological proposal based on secondary data and the main results of the HIV-Sentinel Study among childbearing women, which was carried out in Brazil during 2006. A probabilistic sample of childbearing women was selected in two stages. In the first stage, 150 health establishments were selected, stratified by municipality size, whereas in the second stage, 100-120 women were selected systematically. Significant differences were found according to race, educational level, and municipality size. The proposed methodology is described as low-cost and easy to apply and permits the identification of problems in routine service provision in addition to monitoring compliance with Ministry of Health recommendations for pre-natal care. Almeida et al. ${ }^{49}$ evaluated genotyping and subtyping in antiretroviral-naïve and experienced children and used this information to analyze drug resistance profiles, concluding that rates of primary resistance in antiretroviral-naïve children are low, whereas they are high in children who fail antiretroviral treatment, which is compatible with its use in these patients. Olajubu et al. ${ }^{50}$ described the seroprevalence of HIV among blood donors, antenatal women, and other patients in a tertiary hospital in Nigeria and found that though there is a high prevalence rate among in- and out-patients, many of these patients were screened based on manifestations of clinical symptoms. The prevalence of comorbidities is discussed several papers: Diehl et al. ${ }^{39}$ discussed the simultaneous occurrence of lipodistrophy; Bachur et al. ${ }^{51}$ and Neto et al. ${ }^{52}$ described enteric parasitism relating to highly active antiretroviral therapy; Carvalho et al. ${ }^{53}$ evaluated factors related to the development of tuberculosis in HIV-infected patients in 
Fortaleza, Ceara, Brazil and discussed strategies to improve the control of tuberculosis in HIV-infected patients; and Cavasin et al. ${ }^{54}$ described the incidence of xerostomia, dental caries, and periodontal disease in HIV+ patients.

Risk factors. Two papers cover this subject. Hofer et al. ${ }^{55}$ described factors from the neonatal period associated with long-term non-progression of HIV in a Brazilian cohort of vertically infected children; Mercon et al. ${ }^{56}$ examined a cross section of HIV-infected patients in Rio de Janeiro and found that risk-based assessment does not distinguish between recent and chronic HIV-1 infection.

Comorbidities are an important aspect of HIV, and we have reports of HIV in association with tuberculosis (Carvalho et $\mathrm{al}^{53}$ with enteric parasites (Bachur et al, and Neto et al) ${ }^{51,52}$ with lipodistrophy (Monnerast et al), ${ }^{57}$ and cervical intraepithelial neoplasia (Russomano et al). ${ }^{58}$

Perception of HIV by patients is discussed by Silva et al., ${ }^{59}$ who researched the perception of female vulnerability to infection among university students in Rio de Janeiro and found that the interviewed women recognize vulnerability factors in other women and realize the risk that others face of acquiring HIV but do not consider themselves to be at risk. Almeida et al. ${ }^{60}$ evaluated the knowledge of HIV/AIDS patients concerning antiretroviral drugs and found a lack of general information among users of antiretroviral drugs, and at the same time a need for a better understanding of the problems. They emphasize the need for all health care professionals involved with patients to supply information on prescribed drugs as an ethical component of the treatment that favors and fosters adherence.

\section{Hepatitis}

Hepatitis is a frequent occurrence in recent Brazilian medical literature. Fonseca et al. ${ }^{61}$ developed a Markov model to mirror the natural disease history in cohorts of patients with hepatitis $C$ virus who received peginterferon alpha- $2 b$ with ribavirin or interferon alpha- $2 b$ and ribavirin treatment for 48 or 24 weeks, according to their viral genotype and liver histology; they concluded that peginterferon alpha-2b with ribavirin is a cost-effective therapy for treating naïve chronic hepatitis $C$ adult patients compared to the interferon alpha- $2 \mathrm{~b}$ and ribavirin regime, regardless of the viral genotype. Santos et al. ${ }^{62}$ described fulminant hepatic failure in eight adults and children from a public hospital in Rio de Janeiro, Brazil caused by hepatitis B and one case of severe acute hepatitis caused by hepatitis A. Veras et al. ${ }^{63}$ described the prevalence of chronic hepatitis $C$ virus in the state of Piaui in northeastern Brazil; Zahdi et al. ${ }^{64}$ examined the costs and benefits of preventing the disease by utilizing the vaccine for hepatitis $A$ in the southern Brazilian state of Parana. Schulz et al. ${ }^{65}$ described the results of cerebral magnetic resonance spectroscopy in patients with hepatic encephalopathy with analysis before and after liver transplantation.

Pneumonia. The prevalence of ventilator-associated pneumonia was studied by Rodrigues et al. ${ }^{66}$ in a database of 233 patients on mechanical ventilation, and the investigators concluded that a high incidence of infection with resistant bacteria and inappropriate initial antibiotic therapy with long time on mechanical ventilation and prior use of antibiotics are risk factors for the onset of pneumonia. This study should be analyzed in conjunction with the study by Fortaleza et al., ${ }^{67}$ who described age, central nervous diseases, and the use of antacids as risk factors for hospital-acquired pneumonia in non-ventilated adults. Serefhanoglu et al. ${ }^{68}$ described a prospective casecontrol study (October 2003 to June 2007) that evaluated risk factors for multidrug resistance among extended-spectrumb-lactamase-producing Escherichia coli and Klebsiella spp. (ESBL-EK) isolates in blood cultures. The study included all adult patients ( $>18$ years old) whose blood cultures grew ESBL-EK during the study period and showed that the rate of multidrug resistance among ESBL-EK bloodstream isolates was high and that the duration of hospitalization before bacteremia was the only independent risk factor for the multiple drug resistant ESBL-EK bloodstream infections. Mukai et al. ${ }^{69}$ performed a spatial analysis of hospitalizations for pneumonia in the Vale do Paraiba region of Brazil that determined spatial autocorrelations and identified cities in which interventions are necessary regarding the number of hospitalizations for pneumonia in infants under one year of age. Lopes et al. ${ }^{70}$ studied the immunization of 139 mothers with pneumococcal capsular polysaccharide vaccine during pregnancy randomly allocated to receive/ not receive 23 -valent polysaccharide vaccines during or after pregnancy. Their offspring were monitored monthly over the first 6 months of life, and the results showed that providing the mother with a polysaccharide vaccination during pregnancy did not decrease pneumococcal colonization.

Staphylococcus infections are the object of three papers. Shrestha et al. ${ }^{71}$ described the nasal carriage of Staphylococcus aureus among health care workers in a Nepal hospital. Cury et al. ${ }^{72}$ studied 151 methicillin-resistant (MRSA) strains isolated from patients admitted to tertiary care hospitals in two metropolitan areas (Campinas City and Ribeirao Preto) in the southeast of Brazil through PCRbased techniques and found that the variability among such strains is larger than previously reported, indicating that the techniques used by these authors can be an alternative to pulsed-field gel electrophoresis.

\section{REFERENCES}

1. Santos CE, Schrank Y, Kupfer R. Critical analysis of WHO, IDF and NCEP criteria for metabolic syndrome among patients with type 1 diabetes mellitus. Arq Bras Endocrinol Metabol. 2009;53:1096-102.

2. Rollin G, Punales M, Geremia C, Ce GV, Tschiedel B. Use of insulin glargine in type 1 diabetes children with less than eight years old. Arq Bras Endocrinol Metabol. 2009;53:721-5.

3. Xavier AC, Silva IN, Costa Fde O, Correa DS. Periodontal status in children and adolescents with type 1 diabetes mellitus. Arq Bras Endocrinol Metabol. 2009;53:348-54.

4. Panarotto D, Trasel Hde A, de Oliveira MS, Gravina LB, Teles AR Glycemic control in type 2 diabetic patients in public and private healthcare service. Arq Bras Endocrinol Metabol. 2009;53:733-40.

5. Geloneze B, Vasques AC, Stabe CF, Pareja JC, Rosado LE, Queiroz EC, et al. HOMA1-IR and HOMA2-IR indexes in identifying insulin resistance and metabolic syndrome: Brazilian Metabolic Syndrome Study (BRAMS). Arq Bras Endocrinol Metabol. 2009;53:281-7.

6. Madeira IR, Carvalho CN, Gazolla FM, de Matos HI, Borges MA Bordallo MA. [Cut-off point for Homeostatic Model Assessment for Insulin Resistance (HOMA-IR) index established from Receiver Operating Characteristic (ROC) curve in the detection of metabolic syndrome in overweight pre-pubertal children]. Arq Bras Endocrinol Metabol. 2008;52:1466-73.

7. Mendes LL, Gazzinelli A, Velasquez-Melendez G. Factors associated with insulin resistence in rural populations]. Arq Bras Endocrinol Metabol. 2009;53:332-9

8. Ferreira CL, Ferreira MG. Epidemiological characteristics of diabetic patients within the public health system-an analysis of the HiperDia system. Arq Bras Endocrinol Metabol. 2009;53:80-6.

9. Silva EA, Flexa F, Zanella MT. Impact of abdominal fat and insulin resistance on arterial hypertension in non-obese women. Arq Bras Endocrinol Metabol. 2009;53:340-3. 
10. Vasques AC, Rosado LE, Rosado GP, Ribeiro Rde C, Franceschini Sdo C, Geloneze B, et al. Predictive ability of anthropometric and body composition indicators in the identification of insulin resistance. Arq Bras Endocrinol Metabol. 2009;53:72-9.

11. Caldas AD, Porto AL, Motta LD, Casulari LA. Relationship between insulin and hypogonadism in men with metabolic syndrome. Arq Bras Endocrinol Metabol. 2009;53:1005-11.

12. Ferreira CB, Cesaretti ML, Ginoza M, Kohlmann O, Jr. Metformin effects upon blood pressure and glucose metabolism of monossodium glutamate induced-obese spontaneously hypertensive rats. Arq Bras Endocrinol Metabol. 2009;53:409-15

13. da Paz-Filho GJ, Volaco A, Suplicy HL, Radominski RB, Boguszewski CL. Decrease in leptin production by the adipose tissue in obesity associated with severe metabolic syndrome. Arq Bras Endocrinol Metabol. 2009;53:1088-95.

14. Hinuy HM, Hirata MH, Forti N, Diament J, Sampaio MF, Armaganijan D, et al. Leptin G-2548A promoter polymorphism is associated with increased plasma leptin and BMI in Brazilian women. Arq Bras Endocrinol Metabol. 2008;52:611-6.

15. Geloneze B, Pereira JA, Pareja JC, Lima MM, Lazarin MA, Souza IC, et al. Overcoming metabolic syndrome in severe obesity: adiponectin as a marker of insulin sensitivity and HDL-cholesterol improvements after gastric bypass. Arq Bras Endocrinol Metabol. 2009;53:293-300.

16. Piccoli JC, Gottlieb MG, Castro L, Bodanese LC, Manenti ER, Bogo MR, et al. Association between $894 \mathrm{G}>\mathrm{T}$ endothelial nitric oxide synthase gene polymorphisms and metabolic syndrome. Arq Bras Endocrinol Metabol. 2008;52:1367-73.

17. Cercato C, Halpern A, Frazzatto ES, Guazzelli IC, Villares SM. The N363S polymorphism in the glucocorticoid receptor gene: effects on visceral fat assessed by abdominal computed tomography. Arq Bras Endocrinol Metabol. 2009;53:288-92.

18. Madeira IR, Carvalho CN, Gazolla FM, Pinto LW, Borges MA, Bordallo MA. Impact of obesity on metabolic syndrome components and adipokines in prepubertal children. J Pediatr (Rio J). 2009;85:261-8, doi: $10.2223 /$ JPED.1873

19. Buzinaro EF, Berchieri CB, Haddad AL, Padovani CR, Pimenta Wde P. [Overweight in adolescent offspring of women with hyperglycemia during pregnancy]. Arq Bras Endocrinol Metabol. 2008;52:85-92.

20. Rivera NF, Eisenstein E, Cardoso CB.[The relation between pubertal gynecomastia and body mass index in a sample of adolescents attended at the Outpatient Health Unit of a University Hospital. Arq Bras Endocrinol Metabol. 2009;53:435-9.

21. Bonganha V, Conceicao MS, Dos Santos CF, Chacon-Mikahil MP, Madruga VA. Resting metabolic rate and body composition in postmenopausal women. Arq Bras Endocrinol Metabol. 2009;53: 755-9.

22. Tavares Jde S, Melo AS, Amorim MM, Barros Vde O, Benicio MH, Takito MY, et al. Association between maternal physical activity, gestational weight gain and birth weight in a cohort of 118 pregnant women in Campina Grande, Northeast of Brazil. Rev Assoc Med Bras. 2009;55:335-41.

23. Ballen ML, Moretto VL, Santos MP, Goncalves TS, Kawashita NH, Stoppiglia LF, et al. [Protein restriction in pregnancy: effects related to dam metabolism]. Arq Bras Endocrinol Metabol. 2009;53:87-94.

24. Silva DA, Felisbino-Mendes MS, Pimenta AM, Gazzinelli A, Kac G, Velasquez-Melendez G. Metabolic disorders and adiposity in a rural population. Arq Bras Endocrinol Metabol. 2008;52:489-98.

25. Vedana EH, Peres MA, Neves J, Rocha GC, Longo GZ. Prevalence of obesity and potential causal factors among adults in southern Brazil. Arq Bras Endocrinol Metabol. 2008;52:1156-62.

26. Coltro RS, Mizutani BM, Mutti A, Delia MP, Martinelli LM, Cogni AL, et al. Cardiovascular risk factors in a population attending a community event on health education. Rev Assoc Med Bras. 2009;55:606-10, doi: 10. 1590/S0104-42302009000500028.

27. Nascente FM, Jardim PC, Peixoto Mdo R, Monego ET, Barroso WK, Moreira HG, et al. Hypertension and its association to anthropometric indexes in adults from a small city ln Brazil. Rev Assoc Med Bras. 2009;55:716-22, doi: 10.1590/S0104-42302009000600017.

28. Fernandes RA, Conterato I, Messias KP, Christofaro DG, de Oliveira AR, Freitas Junior IF. Risk factors associated with overweight among adolescents from western Sao Paulo state. Rev Esc Enferm USP. 2009;43:768-73.

29. Coutinho PR, Cecatti JG, Surita FG, Souza JP, Morais SS. Factors associated with low birth weight in a historical series of deliveries in Campinas, Brazil. Rev Assoc Med Bras. 2009;55:692-9, doi: 10.1590/ S0104-42302009000600013.

30. Ferreira SR, Almeida-Pittito B. Reflection about Japanese immigration to Brazil under the light of body adiposity. Arq Bras Endocrinol Metabol. 2009;53:175-82.

31. Yamashita C, Damiao R, Chaim R, Harima HA, Kikuchi M, Franco LJ, et al. [Interethnic marriage of Japanese-Brazilians associated with less healthy food habits and worse cardiometabolic profile. Arq Bras Endocrinol Metabol. 2009;53:485-96.
32. Haun DR, Pitanga FJ, Lessa I. Waist-height ratio compared to other indicators of obesity as predictosr of high coronary risk. Rev Assoc Med Bras. 2009;55:705-11, doi: 10.1590/S0104-42302009000600015.

33. Guedes NG, Moreira RP, Cavalcante TF, de Araujo TL, Ximenes LB. Students' physical activity: an analysis according to Pender's health promotion model. Rev Esc Enferm USP. 2009;43:774-80, doi: 10.1590/ S0080-62342009000400006.

34. Moraes AC, Fernandes CA, Elias RG, Nakashima AT, Reichert FF, Falcao MC. Prevalence of physical inactivity and associated factors in adolescents. Rev Assoc Med Bras. 2009;55:523-8.

35. Santos LC, Cintra IP, Fisberg M, Castro ML, Martini LA. Association among weight loss, bone mass, body composition and dietary intake of post-pubertal obese adolescents. Arq Bras Endocrinol Metabol. 2008;52:1001-8.

36. Prado WL, Siegfried A, Damaso AR, Carnier J, Piano A, Siegfried W. Effects of long-term multidisciplinary inpatient therapy on body composition of severely obese adolescents. J Pediatr (Rio J). 2009;85:243-8, doi: 10.2223/JPED.1889.

37. Fernandes PS, Bernardo Cde O, Campos RM, Vasconcelos FA. Evaluating the effect of nutritional education on the prevalence of overweight/obesity and on foods eaten at primary schools. J Pediatr (Rio J). 2009;85:315-21.

38. Abulnaja KO. Changes in the hormone and lipid profile of obese adolescent Saudi females with acne vulgaris. Braz J Med Biol Res. 2009;42:501-5, doi: 10.1590/S0100-879X2009000600005.

39. Diehl LA, Dias JR, Paes AC, Thomazini MC, Garcia LR, Cinagawa E, et al. Prevalence of HIV-associated lipodystrophy in Brazilian outpatients: relation with metabolic syndrome and cardiovascular risk factors. Arq Bras Endocrinol Metabol. 2008;52:658-67.

40. Serpa Neto A, Rossi FM, Amarante RD, Buriti NA, Rossi M. Impact of plasmatic lipids in glycemic control and its influence in the cardiometabolic risk in morbidly obese subjects. Arq Bras Endocrinol Metabol. 2009;53:747-54.

41. Voltera AF, Cesaretti ML, Ginoza M, Kohlmann O, Jr. Effects of neuroendocrine obesity induction on systemic hemodynamics and left ventricular function of normotensive rats. Arq Bras Endocrinol Metabol. 2008;52:47-54.

42. Orpheu SC, Coltro PS, Scopel GP, Saito FL, Ferreira MC. Body contour surgery in the massive weight loss patient: three year-experience in a secondary public hospital. Rev Assoc Med Bras. 2009;55:427-33, doi: 10. 1590/S0104-42302009000400018.

43. Kurebayashi LF, de Freitas GF, Oguisso T. Nurses' perception about diseases that are treated by acupuncture. Rev Esc Enferm USP. 2009;43:930-6, doi: 10.1590/S0080-62342009000400027.

44. Rech CR, Cordeiro BA, Petroski EL, Vasconcelos FA. Validation of bioelectrical impedance for the prediction of fat-free mass in Brazilian elderly subjects. Arq Bras Endocrinol Metabol. 2008;52:1163-71.

45. Rodrigues AE, Marostegan PF, Mancini MC, Dalcanale L, Melo ME, Cercato $\mathrm{C}$, et al. Analysis of resting metabolic rate evaluated by indirect calorimetry in obese women with low and high caloric intake. Arq Bras Endocrinol Metabol. 2008;52:76-84.

46. Chaves GV, Pereira SE, Saboya CJ, Cortes C, Ramalho R. Abdominal ultrasound and magnetic resonance imaging: a comparative study on the non-alcoholic fatty liver disease diagnosis in morbidly obese patients. Rev Assoc Med Bras. 2009;55:45-9, doi: 10.1590/S0104-42302009000100014.

47. Bassichetto KC, Bergamaschi DP, Veras MA, Sucupira MC, Mesquita F, Diaz RS. Estimating HIV-1 incidence using the serologic testing algorithm for recent HIV infections at HIV counseling and testing centers in the city of Sao Paulo, Brazil. Braz J Infect Dis. 2009;13:9-12, doi: 10.1590/S1413-86702009000100004.

48. Szwarcwald CL, Barbosa Junior A, Souza-Junior PR, Lemos KR, Frias PG Luhm KR, et al. HIV testing during pregnancy: use of secondary data to estimate 2006 test coverage and prevalence in Brazil. Braz J Infect Dis. 2008;12:167-72, doi: 10.1590/S1413-86702008000300002.

49. Almeida FJ, Berezin EN, Rodrigues R, Safadi MA, Arnoni MV, Oliveira C, et al. Diversity and prevalence of antiretroviral genotypic resistance mutations among HIV-1-infected children. J Pediatr (Rio J). 2009;85:1049, doi: 10.2223/JPED.1877.

50. Olajubu FA, Osinupebi OA, Deji-Agboola M, Jagun EO. Seroprevalence of HIV among blood donors, antenatal women and other patients in a tertiary hospital in Nigeria. Braz J Infect Dis. 2009;13:280-3, doi: 10.1590/ S1413-86702009000400008.

51. Bachur TP, Vale JM, Coelho IC, Queiroz TR, Chaves Cde S. Enteric parasitic infections in HIV/AIDS patients before and after the highly active antiretroviral therapy. Braz J Infect Dis. 2008;12:115-22, doi: 10. 1590/S1413-86702008000200004.

52. Neto LM, Oliveira Rde V, Totino PR, Sant'Anna FM, Coelho Vde O, Rolla VC, et al. Enteroparasitosis prevalence and parasitism influence in clinical outcomes of tuberculosis patients with or without HIV coinfection in a reference hospital in Rio de Janeiro (2000-2006). Braz J Infect Dis. 2009;13:427-32, doi: 10.1590/S1413-86702009000600008.

53. Carvalho BM, Monteiro AJ, Pires Neto Rda J, Grangeiro TB, Frota CC. Factors related to HIV/tuberculosis coinfection in a Brazilian reference hospital. Braz J Infect Dis. 2008;12:281-6. 
54. Cavasin Filho JC, Giovani EM. Xerostomy, dental caries and periodontal disease in HIV+ patients. Braz J Infect Dis. 2009;13:13-7, doi: 10.1590/ S1413-86702009000100005.

55. Hofer CB, Oliveira RH, Machado ES, Pala A, Evangelista L, Fernandes I, et al. Neonatal factors associated with HIV long term non-progressors in a cohort of vertically infected children in Rio de Janeiro, Brazil ('Peixe' Project). Braz J Infect Dis. 2009;13:276-9, doi: 10.1590/S1413-86702009000400007.

56. Mercon M, Tuboi SH, Batista SM, Telles SR, Grangeiro JR, Zajdenverg R, et al. Risk-based assessment does not distinguish between recent and chronic HIV-1 infection in Rio de Janeiro, Brazil. Braz J Infect Dis. 2009;13:272-5, doi: 10.1590/S1413-86702009000400006.

57. Monnerat BZ, Cerutti Junior C, Canicali SC, Motta TR. Clinical and biochemical evaluation of HIV-related lipodystrophy in an ambulatory population from the Hospital Universitario Cassiano Antonio de Morais, Vitoria, ES, Brazil. Braz J Infect Dis. 2008;12:364-8, doi: 10.1590/S141386702008000400002

58. Russomano F, Reis A, Camargo MJ, Grinsztejn B, Tristao MA. Recurrence of cervical intraepithelial neoplasia grades 2 or 3 in HIV-infected women treated by large loop excision of the transformation zone (LLETZ). Sao Paulo Med J. 2008;126:17-22, doi: 10.1590/S1516-31802008000100004.

59. Silva CM, Vargens OM. Women's perception about female vulnerability to STD and HIV. Rev Esc Enferm USP. 2009;43:401-6.

60. Almeida RF, Vieira AP. Evaluation of HIV / AIDS patients' knowledge on antiretroviral drugs. Braz J Infect Dis. 2009;13:183-90, doi: 10.1590/S141386702009000300006 .

61. Fonseca MC, Araujo GT, Araujo DV. Cost effectiveness of peginterferon alfa2B combined with ribavirin for the treatment of chronic hepatitis $\mathrm{C}$ in Brazil. Braz J Infect Dis. 2009;13:191-9, doi: 10.1590/S1413-86702009000300007.

62. Santos DC, Martinho JM, Pacheco-Moreira LF, Araujo CC, Oliveira BC, Lago BV, et al. Fulminant hepatitis failure in adults and children from a Public Hospital in Rio de Janeiro, Brazil. Braz J Infect Dis. 2009;13:323-9, doi: $10.1590 /$ S1413-86702009000500002.
63. Veras KN, Jacobina KS, Soares VY, Avelino MA, Vasconcelos Cde M, Parente JM. Chronic hepatitis C virus in the state of Piaui, northeastern Brazil. Braz J Infect Dis. 2009;13:125-9, doi: 10.1590/S1413-86702009000200011.

64. Zahdi MR, Maluf I, Jr., Maluf EM. Hepatitis A: the costs and benefits of the disease prevention by vaccine, Parana, Brazil. Braz J Infect Dis. 2009:13:257-61, doi: 10.1590/S1413-86702009000400003.

65. Schulz GJ, Coelho JC, Matias JE, Campos AC, Schulz DD, Bertoldi GA. Cerebral magnetic resonance spectroscopy in patients with hepatic encephalopathy: analysis before and after liver transplantation. Rev Assoc Med Bras. 2009;55:35-9, doi: 10.1590/S0104-42302009000100012.

66. Rodrigues PM, do Carmo Neto E, Santos LR, Knibel MF. Ventilatorassociated pneumonia: epidemiology and impact on the clinical evolution of ICU patients. J Bras Pneumol. 2009;35:1084-91.

67. Fortaleza CM, Abati PA, Batista MR, Dias A. Risk factors for hospitalacquired pneumonia in nonventilated adults. Braz J Infect Dis. 2009;13:284-8.

68. Serefhanoglu K, Turan H, Timurkaynak FE, Arslan H. Bloodstream infections caused by ESBL-producing E. coli and K. pneumoniae: risk factors for multidrug-resistance. Braz J Infect Dis. 2009;13:403-7.

69. Mukai Ade O, Alves K de S, Nascimento LF. Spatial analysis of hospitalizations for pneumonia in the Vale do Paraiba region of Brazil. J Bras Pneumol. 2009;35753-8.

70. Lopes CR, Berezin EN, Ching TH, Canuto Jde S, Costa VO, Klering EM. Ineffectiveness for infants of immunization of mothers with pneumococcal capsular polysaccharide vaccine during pregnancy. Braz J Infect Dis. 2009;13:104-6, doi: 10.1590/S1413-86702009000200008.

71. Shrestha B, Pokhrel BM, Mohapatra TM. Staphylococcus aureus nasal carriage among health care workers in a Nepal Hospital. Braz J Infect Dis. 2009;13:322, doi: 10.1590/S1413-86702009000500001.

72. Cury GG, Mobilon C, Stehling EG, Lancellotti M, Ramos Mde C, Martinez R, et al. Molecular typing of methicillin-resistant Staphylococcus aureus (MRSA) strains isolated in two metropolitan areas of Sao Paulo State, southeast Brazil. Braz J Infect Dis. 2009;13:165-9, doi: 10. 1590/S1413-86702009000300002. 